\title{
Framework of Values in Primary School Teachers and Education to Sustainable Development
}

\author{
Marianna Piccioli \\ Ph.D \\ Research fellow \\ Department of Education, Languages, Interculture, Literature and Psychology \\ University of Florence \\ Italy \\ $\&$ \\ Ph.D \\ University of Vic - Central University of Catalonia \\ Spain
}

\begin{abstract}
This document aims to present the results of a survey addressed to primary school teachers aimed at exploring how primary school teachers are able to support change and educate about sustainability and how this process of change is perceived and implemented inside the schools.To carry out the survey, some parts of the Index for inclusion were used, which, in the latest version, also addresses environmental issues in a value perspective by introducing sustainability as a fundamental value necessary to create inclusive cultures.The results offer us an interesting cross-section and highlight the permanence of some critical issues that can be traced back to the values of the teachers themselves.
\end{abstract}

Keywords: Education; sustainable development; Index for Inclusion; Primary School; values of teachers

\section{Education to sustainable development}

The Guidelines on environmental education (Miur\& Ministry of Environment, 2014) appoint teachers to a direct responsibility towards the environment and sustainability, defining as strategic the education for sustainable development; furthermore, they make explicit that educating to sustainability requires to activate virtuous processes of overall change in behaviour and lifestyles, an approach that can only be based on the sphere of values rather than on the cognitive one.Edgar Morin (2001) provides us with a framework of thought to face the challenges of the complexity of current environmental, social, economic and institutional systems through what he considers the seven knowledge for the education of the future. In relation to our specific area of interest, the French philosopher invites us to:

- promote a kind of knowledge capable of catching the connection between local and global through the acquisition of strategies that allow to get the links and understand the relationships and mutual influences between the sections and the whole

- recognize the unity and complexity of the human being in a learning context that provides the knowledge dispersed in the disciplines through the understanding that the human being is simultaneously a physical, biological, psychic, cultural, social and historical being

- acquire the awareness that the destiny of mankind is a worldwide reality and that all human beings live the same community of destiny

- to become aware that the human condition consists in being at the same time individual, species and society that leads us to having to promote the joint development of individual autonomies, community participation and conscience of the human species in order to achieve a global and world citizenship..

Following the thinking of the above-mentioned French philosopher, contemporary complexity is embodied in the interrelation between individual systems that interact, condition and influence each other.In this perspective, the sustainability of the environmental system will be characterized by the ability to maintain over time the quality and reproducibility of natural resources by honouring the integrity of the ecosystem with the aim of preserving biodiversity, to prevent the set of elements on which it depends life is altered.The sustainability of the environmental system is interconnected with the system of economic sustainability in the capacity to generate income and work in a lasting way for the sustenance of the population with a view of eco-efficiency of the economy understood, in particular, as a rational and efficient use of resources, with the reduction of the use of non-renewable ones. 
Another system that correlates with the others is the one of social sustainability in its capability to guarantee conditions of human well-being and access to opportunities (safety, health, education, but also amusement, peace of mind, sociability), equally distributed among social strata, age and gender, and in particular between present and future communities.

Finally, the system of institutional sustainability will be linked to the ability to ensure conditions of stability, democracy, participation, information, training, justice, dialogue, assumption of responsibility, involvement of stakeholders.

"One of the challenges of education in our days is to help and transform de facto interdependence into a freely participated solidarity, to contribute to developing a new humanism that has the dignity of the person -and of the environment in which he lives in- at the center"(Birbes, 2011, page 113).

National Guidelines for the curriculum for preschool and first cycle of primary education in 2012 respond to this need by identifying skills to be achieved coherently with the vision set out so far. As a matter of fact, the competences to be reached at the end of primary school include:

- exploration of phenomena with a scientific approach: observation and description of facts, formulation of questions, proposals and implementation of easy experiments;

- identification in the phenomena of similarities and differences, recording and measurement of significant data, identification of space-time relationships;

- identification of quantitative and qualitative aspects, elaboration of simple models, production of simple schemes and relationships using an appropriate language.

The competences expected to be reached by the end of third grade of lower secondary school are obviously richer and include:

- general competences related to the exploration of phenomena, to the research and to the solution of problems using the acquired knowledge;

- competences for schematization and modelling of facts and phenomena using, if necessary, measures and easy formalizations;

- a complex and conscious vision of the potential and limits of science, being science a historically determined and socially responsible human enterprise;

- attitudes of curiosity, interest and rational analysis of reality that should accompany knowledge and awareness.Finally, in the Curricular Guidelines for Compulsory Education dated 2007 (MIUR, Decree 22 August 2007) addressed to children up to sixteen years, the foreseen competences are the following ones:

- observe, describe and analyse the phenomena belonging to natural and artificial reality and recognize the concepts of system and complexity in its various forms;

- analyse qualitatively and quantitatively phenomena related to energy transformations starting from experience;

- be aware of the potential and limitations of technologies in the cultural and social context in which they are applied.

The scientific competences foreseen for the stage of primary school are developed and accomplished during the continuation of the school path in an ascending recursive vision that will bring the student to deepen and to increase his own knowledge.In the 2006 European Union document on key competences, these latter are defined as "a combination of knowledge, skills and appropriate attitudes to the context". Referring to scientific knowledge, they also include "the ability and willingness to use all owned knowledge and methodologies to explain the world around us, knowing how to identify problems and drawing conclusions that are based on proven facts". The attempt is to escape the logic of presentificationthat Bauman (2008) sees in the liquid modern society that leads the person to live the moment, performing actions in consideration of the here and now without questioning the consequences of his own actions in a worldwide and temporal postponed sense.

In Western culture, the relationship between man and nature is often characterized by some contradictions that see,on the one hand,professed principles and,on the other, divergent behaviours not in line with the sameenunciatedprinciples. In particular, personal behaviours are not entirely ecologically oriented towards a collective imagination that sees environmental protection as one of the objectives to be pursued. The same can be said for the model of economic and social development that still does not respond to sustainability logics while the individual systems, procedures and processes are heading towards sustainability monitoring. Not surprisingly, compared with information and communication efforts to promote a global and systemic approach to sustainability issues, the vision of the environment is of a reductionist nature, so there is a tendency to worry about events and behaviours that directly affect the individual in his near context of action. Certainly,the care for the environment is not neglected as long as this does not cause the limitation of one's individual freedom(Mazzata S., 2006). 
"The considerable efforts made in recent decades by scientists in all fields and by ecological movements do not yet seem to be affecting practice and culture to overcome the characteristic Cartesian human-nature duality, based on the assumption that man, as a being gifted of self-awareness, is superior to all other living beings and, therefore, absolute lord of the destiny of the Creation" (Ibid., pages 90-91).

Continuing with the reflection on culture and the system of values LuiginaMortari (2001) argues that "the ecological crisis would have among its most remote causes also a series of knowledge-building procedures which, if on the one hand proved to be effective with respect to the moderndream to arrive at giving and exploiting nature, on the other hand they have caused the construction of a reductive and simplifying knowledge with respect to the complexity of biological life"(Ibid., page 35).

It is clear that the activation of the renewal process from the perspective of sustainability should start with educational interventions aimed at influencing the categories of values of their students.From this point of view, how much are schools and teachers capable of supporting change and educating to sustainability? And which processes and tools could be useful to carry out this path?

\section{Education for sustainable development and Index for Inclusion}

One of the aims of the Index for Inclusion, proposing to schools a recursive path of self-assessment and selfimprovement in an inclusive perspective, is to relate actions to values, and one of the values on which it is founded is sustainability.

The Index for Inclusion was published in Great Britain for the first time in 2000 by Tony Booth and Mel Ainscow from the Center for Studies on Inclusive Education following a three-year itinerary that involved around thirty schools with involvement of teachers, parents, administrators and researchers. This first version was subsequently modified in 2002 and from 2004 to 2006 adapted versions were developed for other educational contexts, up to the first partial translation in Italian language of 2006 contained in a text by Roberto Medeghini. Later, with the support of UNESCO, the development of versions of the Index for Inclusion addressed to economically disadvantaged national contexts located in the southern hemisphere was designed. In Italy, despite its first partial translation, the Index for inclusion began to gain visibility in 2008 after its complete translation by Enrico Valtellina, published in a volume edited by Fabio Dovigo and Dario Ianes. Recently the third version of Booth and Ainscow dated 2011 was translated into Italianby Fabio Dovigo (2014).

This new version arises from its experimentation in the field and, according to the authors'view, "work on inclusive values has been extended and used to give unity to interventions based on principles, such as those on environmental sustainability, national and global citizenship, on non-violence and health promotion"(Booth \&Aincow, 2014, page 32). This perspective is realized with a new part of the Index dedicated to the development of the school curriculum in an inclusive perspective.

The Index for Inclusion is founded on the belief that inclusive practices derive from inclusive choices based on inclusive cultures and the graphic representation to which the authors referto is an equilater altriangle whose base correspondstocreating inclusive cultures.

As briefly mentioned, sustainability is, in the Index perspective, one of the values on which the culture of inclusion is based; actually, sustainability as an inclusive valuesees as a fundamental goal of education "preparing children and young people for sustainable life styles inside communities and environments which are sustainable as well, atlocal and global level"(Ibid., page 53). Sustainability is seenas a central issue for the inclusion of millions of people around the world who see their lives in danger because of deforestation, environmental degradation and global warming. The indexis a tool designed to support and guide schools in a process of reflection, self-analysis and self-assessment in the vision of self-improvement in its founding dimensions, cultures, policiesand inclusive practices, proposing multiple indicators and for eseeing that the schools themselve scanidentify and choosethose that they deemmostfunctional in their specific context. For our specific focus, education for sustainability, the authors propose some specific indicators of the three dimensions that can be used within schools to complete a pathofself-improvement.

\section{Exploratory survey on the framework of values in primary school teachers}

In relation to what has been said previously, the possibility of curricula and teaching practices responding to the principles of education for sustainable development is based on the framework of values of the teachers. The Index for Inclusion provides us with a tool that has already been tested in this perspective and is an impulse to self-improvement in schools.The survey involved primary school teachers from 23 institutes in Tuscany who participated in another research project that included the use of the Index for Inclusion as a tool to improve the quality levels of school inclusion. 
The indicators proposed by the Index have been used to detect culture, policies and practices in relation to education for sustainable development. The questionnaire was filled in by 410 teachers online through a Google form. Primary school teachers had to express how much they agreed with the proposed statements on a 5-variable Likert scale. The proposed statements are shown here below, divided by dimensions.

Global dimension

- The schoolencourages the understanding of the relationships between people, everywhere in the world

- The school is committed in stimulating the understanding of similarities and differences between people

- Students study and ask themselves about the Earth, the solar system and the universe

- Students study and ask themselves about life in the terrestrial environment

- The school is a model of democratic citizenship

Dimension of inclusion, participation and community

- Inclusion is seen as a way to increase everyone's participation

- Children and adults are sensitive to the various ways in which the difference appears

- The school is committed to developing the understanding of similarities and differences between people

- The school develops inclusive shared values

- The school promotes respect for human rights

- The school encourages children and adults to feel well with themselves

- The school helps to promote the health of children and adults

- The school motivates pupils to understand the importance of people's health and relationships between individuals

Dimension of sustainable development

- The school encourages to respect the integrity of our planet

- The school reduces the use of water

- The school contributes to waste reduction

- The school encourages pupils to research on the importance of water

- The school encourages pupils to research on energy sources

- The school encourages pupils to deepen cycles of food production and consumption

- The school encourages pupils to reflect on how and why people move both in the local context and in the global context

- The school encourages pupils to analyze housing structures and the relationship between buildings and the natural environment

- The school encourages pupils to reflect on clothing and body care

From the analysis of the answers concerning the global dimension (Tab: 1) emerges that the majority of the respondents agrees enough to the proposed statements but it is interesting to note that the indication of the lack of agreement appears to be the second variable specified in all the suggested indicators.

\begin{tabular}{|l|l|l|l|l|l|}
\hline Global Dimension & $\begin{array}{l}\text { Very } \\
\text { much } \\
\%\end{array}$ & $\begin{array}{l}\text { Enough } \\
\%\end{array}$ & $\begin{array}{l}\text { Few } \\
\%\end{array}$ & $\begin{array}{l}\text { Very } \\
\text { few } \\
\%\end{array}$ & $\begin{array}{l}\text { More } \\
\text { information } \\
\text { is needed } \\
\%\end{array}$ \\
\hline $\begin{array}{l}\text { The school encourages the understanding of the relationships } \\
\text { between people, everywhere in the world }\end{array}$ & 7,3 & 56,1 & 31,7 & 4,9 & 0 \\
\hline $\begin{array}{l}\text { The school is committed in stimulating the understanding of } \\
\text { similarities and differences between people }\end{array}$ & 24,4 & 51,2 & 24,4 & 0 & 0 \\
\hline $\begin{array}{l}\text { Students study and ask themselves about the Earth, the solar } \\
\text { system and the universe }\end{array}$ & 14,6 & 51,2 & 29,3 & 2,4 & 0 \\
\hline $\begin{array}{l}\text { Students study and ask themselves about life in the terrestrial } \\
\text { environment } \\
\text { The school is a model of democratic citizenship }\end{array}$ & 19,5 & 51,2 & 26,8 & 2,4 & 0 \\
\hline
\end{tabular}

Tab: 1. Answers in percentage data related to the global dimension

Regarding the dimension of inclusion, participation and community (Tab: 2) the results still give us a prevalence in being fairly in agreement with the proposed statements. 
Nevertheless, the situation is more fragmented and some statements give us a more complex picture. Inclusion is considered a way to increase the participation of everybodywhile the sensitivity in recognizing the various types of difference is less perceived, and finally the promotion of human rights by the school is indicated as a strong point of educational action.

\begin{tabular}{|l|l|l|l|l|l|}
\hline $\begin{array}{l}\text { Dimension of inclusion, participation and } \\
\text { community }\end{array}$ & $\begin{array}{l}\text { Very } \\
\text { much } \\
\%\end{array}$ & $\begin{array}{l}\text { Enough } \\
\%\end{array}$ & $\begin{array}{l}\text { Few } \\
\%\end{array}$ & $\begin{array}{l}\text { Very few } \\
\%\end{array}$ & $\begin{array}{l}\text { More } \\
\text { information } \\
\text { is needed } \\
\%\end{array}$ \\
\hline $\begin{array}{l}\text { Inclusion is seen as a way to increase } \\
\text { everyone's participation }\end{array}$ & 36,6 & 39 & 12,2 & 9,8 & 2,4 \\
\hline $\begin{array}{l}\text { Children and adults are sensitive to the various } \\
\text { ways in which the difference appears }\end{array}$ & 14,6 & 51,2 & 24,4 & 7,3 & 2,4 \\
\hline $\begin{array}{l}\text { The school is committed to developing the } \\
\text { understanding of similarities and differences } \\
\text { between people }\end{array}$ & 22 & 48,8 & 22 & 7,3 & 0 \\
\hline $\begin{array}{l}\text { The school develops inclusive shared values } \\
\text { The school promotes respect for human rights }\end{array}$ & 26,8 & 46,6 & 48,8 & 14,6 & 0 \\
\hline $\begin{array}{l}\text { The school encourages children and adults to } \\
\text { feel well with themselves }\end{array}$ & 26,8 & 39 & 24,4 & 7,3 & 0 \\
\hline $\begin{array}{l}\text { The school helps to promote the health of } \\
\text { children and adults }\end{array}$ & 24,4 & 43,9 & 24,4 & 4,9 & 2,4 \\
\hline $\begin{array}{l}\text { The school motivates pupils to understand the } \\
\text { importance of people's health and relationships } \\
\text { between individuals }\end{array}$ & 26,8 & 36,6 & 22 & 12,2 & 2,4 \\
\hline
\end{tabular}

Tab: 2. Dimension of inclusion, participation and community

After analyzing the answers given to the general indicators (Tab: 1) and those intended to detect the perception of inclusion, participation and community (Tab: 2), the dimension most specifically attributable to our field of study on sustainable development (Tab: 3), gives us a situation no longer linear as the previous ones. Respondents quite agree that the school encourages respect for the integrity of our planet but, at this first substantial concordance, many points of fall are identified, the most significant of which are those on the use and importance of water, energy sources, food production cycles, clothing and body care. Finally, a negative perception emerges on the phenomena of relocation of people both in the local context and in the global context, a negativity that increases in relation to the analysis of buildings in relation to the natural environment.

\begin{tabular}{|c|c|c|c|c|c|}
\hline Dimension of sustainabledevelopment & $\begin{array}{l}\text { Very much } \\
\%\end{array}$ & $\begin{array}{l}\text { Enough } \\
\%\end{array}$ & $\begin{array}{l}\text { Few } \\
\%\end{array}$ & $\begin{array}{l}\text { Very few } \\
\%\end{array}$ & $\begin{array}{l}\text { More } \\
\text { information is } \\
\text { needed } \\
\%\end{array}$ \\
\hline The school encourages to respect the integrity of our planet & 14,6 & 58,5 & 26,8 & 0 & 0 \\
\hline The school reduces the use of water & 2,4 & 46,3 & 31,7 & 14,6 & 4,9 \\
\hline The school contributes to waste reduction & 19,5 & 41,5 & 29,3 & 4,9 & 4,9 \\
\hline The school encourages pupils to research on the importance of water & 22 & 31,3 & 24,4 & 17,1 & 4,9 \\
\hline The school encourages pupils to research on energy sources & 14,6 & 39 & 29,3 & 14,6 & 2,4 \\
\hline $\begin{array}{l}\text { The school encourages pupils to deepen cycles of food the production and } \\
\text { consumption }\end{array}$ & 22 & 24,4 & 31,7 & 17,1 & 4,9 \\
\hline $\begin{array}{l}\text { The school encourages pupils to reflect on how and why people move } \\
\text { both in the local context and in the global context }\end{array}$ & 7,3 & 29,3 & 39 & 19,5 & 4,9 \\
\hline $\begin{array}{l}\text { The school encourages pupils to analyze housing structures and the } \\
\text { relationship between buildings and the natural environment }\end{array}$ & 2,4 & 24,4 & 41,5 & 24,4 & 7,3 \\
\hline The school encourages pupils to reflect on clothing and body care & 22 & 17,1 & 39 & 17,1 & 4,9 \\
\hline
\end{tabular}

Tab: 3. Dimension of sustainabledevelopment 


\section{Conclusions}

This exploratory survey uses a small sample, limited to 23 scholastic contexts and the primary school teachers who participated in the survey are 410, certainly not a relevant quantity. The data, however, provide us with a picture of perception that we must surely consider as a trend that highlights some points of fall in the values of teachers. The indicators proposed by the Index on education for sustainable development, put forward affirmations relating to the practices, which, as mentioned above, are activated in relation to the value system of those who implement them. Thus we would have expected that the practices in the school, with respect to our area of interest, were more and outstandingly responsive to high levels of perception of agreement, but this did not happen. The teachers, challenged with some affirmations, brought out, after an initial agreement on the general principle concerning the respect of the integrity of our planet, that their educational action for sustainable development comes to a standstill in almost all individual issues, with the exception of waste reduction. The exploratory survey shows us that the framework of valuesin participating primary school teachers is significantly high in the assertions of a more general nature but presents points of moving back when considering the single problems that together compose the general data, not making these types of assertions correspond to practical actions. This trend seems to confirm that the behaviors of the primary school teachers involved often deviate from the principles, in relation to the value framework assumed by the individual person.

\section{Bibliography}

Bauman Z. (2008). Vita liquida. Bari: Laterza.

Birbes C. (Ed.). (2011) Progettare l'educazione per lo sviluppo sostenibile: Idee, percorsi, azioni. Milano: ASA.

Booth T. \&Ainscow M. (2002) Index for Inclusion: developing learning and participation in schools. Bristol. CSIE.

Booth T. \&Ainscow M. ItaliantranslationValtellina E., ItalianeditionDovigo F. \&Ianes D. (Ed.). (2008). L'index per l'inclusione. Promuovere l'apprendimento e la partecipazione nella scuola. Trento: Erickson.

Booth T. \&Ainscow M., Italian edition Dovigo F. (Ed.). (2014), Nuovo index per l'inclusione. Percorsi di apprendimento e partecipazione a scuola, Roma: Carocci Faber, Roma.

Mazzata S. (2006). Cultura ambientale e comunicazione: dall'informazione ai significati, in L. Caimi (Ed.), Coscienza ambientale e educazione alla legalità. Milano: Vita e pensiero.

Medeghini R., (2006). Dalla qualità dell'integrazione all'inclusione. Analisi degli indicatori di qualità per l'inclusione. Brescia: Vannini.

Miur\& Ministero dell'Ambiente. (2014). Educazione ambientale per lo sviluppo sostenibile.

MIUR. (2007). Decreto 22 agosto 2007. Regolamento recante norme in materia di adempimento dell'obbligo di istruzione.

MIUR. (2012). Indicazioni nazionali per il curricolo della scuola dell'infanzia e del primo ciclo d'istruzione.

Morin E. (2001). I sette saperi necessari all'educazione del futuro. Milano: Cortina Raffaello.

Mortari L.. (2001) Per una pedagogia ecologica. Prospettive teoriche e ricerche empiriche sull'educazione ambientate. Milano: La Nuova Italia.

Unione Europea. (2016). Raccomandazione del Parlamento Europeo e del Consiglio del 18 dicembre 2006 relativa a competenze chiave per l'apprendimento permanente. Last consultation 5 giugno 2017, from http://eurlex.europa.eu/LexUriServ/LexUriServ.do?uri=OJ:L:2006:394:0010:0018:it:PDF. 